\title{
The British Association and a Centenary Fund.
}

$\mathrm{I}^{\mathrm{N}}$ 1931 the British Association for the Advancement of Science will hold its centenary meeting in London. No more appropriate place of meeting could have been selected. The Association may justly claim to be fully representative of science as a whole within the British Isles; by its overseas meetings it has stimulated scientific activities and focused the aims and interests of scientific workers in the dominions and dependencies. This dual function makes it inevitable that so momentous an occasion in its history should be endowed with a significance which can most fittingly find expression only in the capital city of the Empire.

The imperial character of the meeting and the place in which it is to be held will make serious demands on the organisation and resources of the Association. On normal occasions the annual meeting is a heavy burden, financial and otherwise, on the locality in which it is held. In London expenditure will be altogether on a higher scale. 'The cost of entertainment of foreign guests and visitors from the dominions and dependencies, if it is to be such as will be regarded as commensurate to the occasion, will be far beyond anything the Association has been able to contemplate hitherto. Without entering into detail, it is abundantly clear that the financial resources of the Association, derived as they are largely from subscriptions which are liable to fluctuation and on ordinary occasions provide no very large margin over the expenses incurred, cannot be relied upon to produce the sum which will be required.

The British Association, having this in view, proposes to raise a fund for its centenary which will be sufficient to meet necessary and desirable expenditure for the meeting. But, in addition, it asks for a sum which will place its finances on a basis adequate for the future development of the Association's approved activities. The appeal was launched at the opening of the recent meeting at Bristol. Everyone connected with scientific work in Great Britain would surely wish that the centenary of the Association should be celebrated with the dignity and circumstance befitting the occasion ; but it is perhaps only those who have been intimately in touch with the inner working of the Association who will appreciate fully all that is implied in the reference to the future development of its work.

During the hundred years of its existence, the Association has striven for the advancement of science primarily by promoting intercourse between scientific workers through its annual meetings. By encouraging the attendance of those not specifically engaged in scientific work or even not specially trained in any one branch of science, the Association has endeavoured to extend the interest in science among the public, especially when occasion offers in regard to its practical application to the affairs of everyday life. While a larger public has been made aware of this side of the Association's work through the good offices of the daily press in reporting the proceedings in the sections and at general meetings, it has had little opportunity to appreciate the valuable support given to research by the money grants administered through research committees. These grants, made year by year on the nomination of the sectional committees representative of the various sciences comprised within the Association, constitute one of the greatest, if not the greatest, of its services in the advancement of science. Many of the committees have produced results of national and even international importance. Even though the sources outside the Association from which grants for research are available have increased in recent years, the assistance of the Association is still in demand, especially in the initial stages of research. At the present moment, indeed, the Association maintains some seventy research committees distributed among the various sciences. For some years the Association has disbursed an average annual amount of $£ 1100$ on the work of its committees-a sum expended entirely in the actual cost of research, the members of the committees receiving no remuneration for their work. The amount available for these grants is to a great degree dependent upon the amount of the subscriptions received, and in the past has frequently been inadequate to the demands.

It is probable that the public is not aware that the activities of the Association are not confined to the duration of each annual meeting. In the interval between sessions the organisation of the Association is not even solely engaged in preparing for its next meeting, heavy as is the work entailed thereby. The Council is also occupied in giving effect to the resolutions passed at the preceding annual meeting, which are usually of considerable moment and, as they frequently affect public interests or policy, involve the submission of the resolutions to Government departments, administrative bodies, and kindred societies. Further, the Council may be said to hold a watching brief for science throughout the year. It is prepared to take action, if need arises, in all matters in which science may be directly or indirectly affected.

While other aspects of the Association's work must here be passed over, reference may be made to the Association's custody of Down House, the home of Darwin, which will in future entail no inconsiderable expense.

The annual income of the Association at the moment is about $£ 5600$, of which nearly a half is derived from the fluctuating annual subscriptions. The amount at which the Association aims for its fund has been put at $£ 40,000$. If from the sum raised part is added to endowment, the Association will be placed in a position to assure its activities and extend them in directions which cannot fail to be of advantage to science. In particular, the amount available for research will be increased; the burden of the annual meetings, now so heavy on the place of meeting, may be somewhat lightened, and the imperial obligations of the Association, 
which have come increasingly into prominence of late years, may be more adequately met.

It should be scarcely necessary to press the claim of the Association in further detail. The position which it has won by its work during the past hundred years is a sufficient warranty of its deserts and of its fitness to administer wisely any funds committed to its charge. On the ground of its services to science and to the community, the Association has well earned the right to expect the support for which it asks.

The greater part of the Bristol meeting of the British Association was favoured by fine weather, of which full advantage was taken by all the sections. Owing to the easy access of many points of special interest, these purely sectional excursions were more fully organised than is usually the case. The Norman Lockyer Observatory at Sidmouth was visited by a party of physicists and astronomers, while Wookey Hole and the Mendips attracted geographers, zoologists, geologists, and anthropologists. The Forest of Dean was included with other excursions by botanists. In the sections themselves, apart from the presidential address, physicists listened with great interest to a summary of the present state of the theory of cohesion by Prof. Lennard-Jones, who showed that through the new mechanics a most promising theory is at last in the process of development. The subject of the present position of the British dyestuff industry provoked an important discussion in Section B, to which many well-known academic and industrial chemists contributed. The memorial lecture to Dr. Beddoe by Sir Arthur Keith emphasised the important anthropological work which has been and is still being done in Bristol, which Sir Arthur pleaded should be recognised by the foundation of a chair in that subject in the University. Airships, both British and German, naturally attracted engineers in Section G; while members had an opportunity of seeing the gyroplane in action at the new Bristol airport. The largest available theatre was filled for a joint discussion between geology, geography, and anthropology, on the relation between past pluvial and glacial periods, under the chairmanship of Prof. Fleure.

The following were included amongst the foreign guests present at the meeting: Section $A$ (Mathematical and Physical Sciences): Prof. R. S. Mulliken (Chicago), M. R. Bureau (Paris), Prof.
M. Siegbahn (Uppsala), Prof. Van Vleck (Wisconsin); Section $B$ (Chemistry) : Prof. J. H. Hildebrand (Berkeley, California); Section C (Geology): Prof. G. Delépine (Lille); Section D (Zoology): Prof. D. de Lange (Utrecht); Section $E$ (Geography) : Prof. A. E. Douglass (Tucson, Arizona); Section $G$ (Engineering) : Prof. A. E. Kennelly (Cambridge, Massachusetts); Section $H$ (Anthropology): Prof. E. Fischer (Berlin-Dahlem), Dr. M. Vassitz (Belgrade); Section K (Botany) : Prof. T. H. Goodspeed (Berkeley, California), Prof. D. H. Campbell (Stanford, California), Prof. W. J. V. Osterhout (New York), Prof. F. A. F. Went (Utrecht).

The total membership for the Bristol meeting was 2650 .

The General Committee of the Association has approved the arrangements made by the Council for the centenary meeting to be held in London next year. The president will be the Right Hon. J. C. Smuts, and a long list of vice-presidents prepared by the Council, together with a representative London Committee, was also accepted by the General Committee.

As the Albert Hall will not be available for the inaugural meeting in London, the Council booked the Wesleyan Central Hall and annexes for this meeting. The General Committee approved of this and also of the proposal that the inaugural meeting should be devoted mainly to receiving addresses and other messages, the president-elect finally addressing the meeting. His presidential address will, however, be delivered on a separate occasion, namely, the final evening of the meeting, Tuesday, Sept. 29. The reception room, sectional meeting rooms, etc., will be in and near Exhibition Road, South Kensington, at such institutions as the University of London, Imperial College of Science, Imperial Institute Science Museum, Victoria and Albert Museum, Royal College of Music, and the Royal Geographical Society.

The new members of Council elected by the General Committee are: Prof. H. Clay, Prof. W. T. Gordon, Dr. C. W. Kimmins, Sir Peter Chalmers Mitchell, and Dr. H. T. Tizard.

The meeting of the Association in 1932 will be held at York, and in 1933 at Leicester. The Lord Provost of Aberdeen and the Principal of the University, Sir George Adam Smith, attended the meeting of the General Committee on Sept. 5 to invite the Association to meet at Aberdeen in 1934, and the invitation was unanimously accepted.

\section{News and Views.}

THE fact that definitely anti-social actions have been committed under the cloak of rationalisation is responsible for many of the misgivings with which labour regards the rationalisation of industry. Moreover, the displacement of workers by machinery has led to some distrust of science by labour. Labour-saving machinery is too often labour-displacing machinery, and although mechanical science is gradually eliminating from industry many of the most unhealthy and exacting conditions of labour, notably in the mining and metallurgical industries, science is often held responsible for creating unemployment. Labour frequently fails to realise that originative discoveries of science create new demands and open fresh avenues of employment in which displaced labour is absorbed. Such discoveries are, of course, those with which science is most closely associated. In this connexion, addresses such as that given by Sir Richard Gregory on Sept. 7, in connexion with the Bristol meeting of the British Association, before the Bristol Branch of the 